\title{
DiRECT DEMOCRACY IN THE EUROPEANUNION:HOW COMPARATIVE FEDERALISM CAN HELP US UNDERSTAND THE INTERPLAY OF Direct DeMOCRACY AND EUROPEAN INTEGRATION*
}

\author{
Democracia directa en la Unión Europea: Cómo una perspectiva de \\ federalismo comparativo nos puede ayudar investigar la interacción \\ entre la democracia directa y el proceso de integración europeo
}

\section{FERNANDO MENDEZ}

Centre for Research on Direct Democracy, University of Zurich

\author{
MARIO MENDEZ \\ School of Law, Queen Mary University of London
}

\section{VASILIKI TRIGA}

Centre for Research on Direct Democracy, University of Zurich

\begin{abstract}
In recent decades Europe's political landscape has been marked by a notable rise in the use of mechanisms of direct democracy such as the referendum and the citizens' initiative. Our focus in this article is on the national referendums directly connected to the European Union (EU) integration process, a subject which is receiving increasing scholarly attention. Two interrelated questions are asked. First, how do these specific mechanisms of direct democracy interact with the existing federal political institutions of the EU? And, second, how does this affect the institutional stability of the EU polity? In addressing this problematique we undertake a cross-polity comparison of the EU-variant of direct democracy that reveals a range of institutional models and brings to the fore a neglected dimension in the study of EU referendum politics, the role of federal political institutions.
\end{abstract}

Keywords: Direct Democracy, European Union, federalism, European integration.

\begin{abstract}
RESUMEN
Durante las últimas décadas ha habido un notable aumento en el uso de mecanismos de democracia directa como el referéndum y la iniciativa popular en el espacio político europeo. El objetivo de este artículo es analizar los referéndums que están directamente vinculados al proceso de integración de la Unión Europea (UE), un tema que está recibiendo mayor atención de la academia. Se platean dos cuestiones interrelacionadas. En primer lugar, icómo se relacionan los mecanismos de democracia directa con las instituciones federales de la UE? Y, en segundo lugar, ¿cómo afecta esto a la estabilidad institucional de la UE? Para investigar este tema se realiza un estudio comparado de la democracia directa en la UE que nos proporciona varios modelos institucionales y pone de manifiesto el papel que juegan las instituciones federales.
\end{abstract}

Palabras clave: Democracia Directa, Unión Europea, federalismo, integración europea.

* The authors are indebted to Andreas Auer, Michael Peart, and Jonathan Wheatley for their comments. We also thank two anonymous referees for their extensive and insightful comments on an earlier draft of this article. Responsibility for any remaining errors and omissions rests entirely with the authors. This research was supported by the Swiss National Science Foundation (Grant no. 100015-116183). 


\section{INTRODUCTION}

The politics surrounding EU related referendums has received a great deal of scholarly attention recently. In large part, this is due to the fact that referendums on EU integration can, and do, produce extra-territorial effects beyond the particular member state holding the referendum. It is in this sense that the growing use of this particular device of direct democracy has potentially significant polity-wide consequences. In fact, it is this very potentiality which underpins the research question at the core of this article, whether the member state referendums on the EU integration process are a source of institutional instability. Such referendums can obviously act as a brake on further integration. But this need not be a source of instability. Indeed, contrary to political commentators and pundits who see an institutional 'crisis' each time the EU integration process stalls, the veto point offered by national referendums constitutes a potentially important check on unwanted centralisation. Thus, paradoxically, and contrary to conventional wisdom, member state referendums on EU matters could actually be a stability inducing mechanism. This raises an interesting empirical puzzle with considerable institutional implications.

This article's point of departure is that in order to satisfactorily analyse the puzzle -whether the rise of direct democracy in the EU is a source of instability or, paradoxically, a potentially stabilising force -the analyst must look beyond the confines of the EU. This approach is rarely undertaken in the literature on EU- related referendums. Thus, despite the fact that many analyses in the literature are comparative, this usually takes the form of an intra-EU comparison (e.g. comparing voter or elite behaviour across member states of the EU) rather than comparing the EU with other polities. We contend that by applying the comparative method -in terms of an explicit cross-polity comparison- we are offered a potentially rewarding research laboratory for investigating how mechanisms of direct democracy interact with federal political institutions across a sample of cases. Highlighting the similarities and differences in specific institutional configurations allows us to compare how distinct political systems have coped with the tensions generated between federalism and direct democracy. This yields comparative insights that can then be applied to the EU case for analysing current models of institutional design as well as investigating possible future institutional trajectories.

This rest of this article is structured as follows. First, it reviews the state-of-the-art on EU referendum politics. Section 3 then sets out a comparative federalism framework as a tool for case selection. It suggests areas where the interplay of federal and direct democratic political institutions could be investigated. In section 4 , this heuristic is applied to the selected cases to reveal a number of institutional models. Sections 5 and 6 then examine the models against the EU-related referendum experience. The analysis takes two forms: the first step presents the evidence on EU-related referendums with a view to examining the specific interaction between federalism and direct democracy; the second step, more qualitatively oriented, offers an analytical narrative on the recent and ill-fated European Constitution. Here, the object of the analysis is to investigate the impact of direct democracy on sources of institutional stability. Based on the preceding analyses, the last section concludes by examining the institutional implications and viability of each model in the EU context. 


\section{STATE-OF-THE-ART ON EU REFERENDUM POLITICS}

The referendum politics of the EU can be approached from a number of disciplinary angles. In this brief overview, we shall concentrate primarily on the political science literature, although important contributions from the field of law, and especially from constitutional lawyers, need to be acknowledged. For heuristic purposes, we can classify the literature into four broad categories, though, as with most efforts of this nature, the distinctions between categories are often blurred. In fact, the best scholarship tends to span most of the categories suggesting that it is more a question of the degree to which author(s) privilege a particular dimension.

1) Normative: This type of approach is dominated by the contributions of legal scholars. Not surprisingly, the focus is on the legal and constitutional provisions to hold a referendum either in a single member state or, from a more comparative perspective, across EU member states. Much of the focus turns on the constitutional implications of member state referendums on EU integration and its impact on the EU polity as a whole (see e.g. the various contributions in Albi \& Ziller, 2007; Pernice, 2006; Auer, 2005; Auer \& Flauss, 1997). Issues of accountability and legitimacy are usually at the core of these studies as is the interplay of constitutionalism and mechanisms of direct democracy.

2) Institutionalist: Operating at the macro-level, recent institutionalist approaches have focused on trying to explain the occurrence of referendums and the reasons why governments decide to hold referendums by cognitive factors and norms. These studies are descriptive in their majority (Qvortrup, 2002, 2006; Setälä, 1999; Bogdanor, 1994) and tend to rely on qualitative methodologies. Sometimes the analysis takes the form of assessing the relative merits of rationalist versus ideational approaches in explaining EU referendum domino effects such as those around the European Constitution (Closa, 2007).

3) Behaviourist: Although most of these studies are 'institutionalist', they can be differentiated from category 2 in terms of their reliance on quantitative methodologies and/or spatial modelling. This could be considered as the dominant approach and it draws heavily from the literature on political behaviour. One set of explanations attributes voting behaviour in EU referendums to individuals' values, beliefs or underlying attitudes towards European integration (Svensson, 1994, 2002, 2007; Franklin et al., 1994; Siune et al., 1994); others focus on the evaluation of symbolic political considerations, (i.e. feelings of national identity) in relation to preferences on EU integration and their effects on voting in EU referendums (Hooghe \& Marks, 2005; Carey, 2002; McLaren, 2002). Another set of studies have examined how the salience of the issue of European integration affects the ability of voters to make competent and reasoned decisions in a European context (see Christin et al., 2002; Franklin, 2002). There is also an increasing number of behaviourist studies that analyse the effects of political parties on holding referendums (Hooghe et al., 2002; Marks et al., 2002; Hix, 1999). Indeed, this has generated a lively debate on whether party positioning is top-down (from elites to masses) or bottom-up (from constituents to party elites) (Ray, 2003) or a combination of the two processes (Steenbergen et al., 2007). Finally, we should mention the influential work of Hug (2002) due to its systematic theoretical, empirical and comparative framework. Hug employs formal modelling to test the impact 
of legal-constitutional factors on patterns of voting behaviour (see also Hug \& Sciarini, 2000; Schneider \& Weitsman, 1996).

4) Comparative: Explicitly comparative approaches, by which we mean comparing the EU-related referendum experience with other polities, are characterised by their conspicuous absence. Trechsel's (2005) structured comparison of the unanimity constraint in Switzerland, the US and the EU, and how in the latter case it has not been overcome, is a rare exception. The absence of explicit comparison is a peculiar lacuna in the field since comparison could, conceivably, take a variety of forms. The origins, operation, and sustainability of EU-related mechanisms of direct democracy are topics which, we argue, invite comparison. Each of these dimensions, in theory, could be compared to experiences in other polities thereby shedding comparative insights on the EU. No doubt because we are intervening in a process that is in its infancy, this is rarely done. In this article we shall pursue this specific comparative route.

\section{COMPARATIVE FEDERALISM AS A TOOL FOR CASE SELECTION}

Federalism was famously described by one of its most prominent scholars, William Riker, as a theory of government that uses a system of checks and balances to curb power and offers an alternative to empire (Riker, 1964). This being so, it is surprising how the federalism dimension has been conspicuously absent from analyses of the EU's experience with referendums. If anything, the EU's most recent referendum experience has demonstrated the 'check' function of member state referendums on the perceived centralising ambitions of EU elites -at least from the perspective of 'no' voters. Could these types of referendums be added to the list of so-called 'federal safeguards' that scholars of comparative federalism argue contribute to the stability of federal systems? And, if not presently the case, is there any institutional configuration where this could occur? These are intriguing questions that raise issues of present, and future, institutional design. In order to investigate these core research questions -namely the interplay of federalism and direct democracy in the European integration process and its impact on institutional (in)stability- let us start by making clear our initial premises and follow this up with some definitions.

Our starting premise is that the EU polity can be compared to other political systems. In terms of institutional features it is closest to a special class of political system: a federal system. There is a growing literature on the EU and comparative federalism that provides ample support for this understanding (e.g. McKay, 2001; Menon and Schain, 2006). Therefore, to the extent that the EU has features comparable to more mature political systems, we are well advised to explore the explanatory value of the comparative method and, by implication, this applies with equal validity to the study of EU-related direct democracy. A second premise, drawn from the comparative federalism literature, is that federalism is an inherently unstable institutional arrangement (Lemco, 2001; Kelemen, 2007). It is important to clarify what exactly is meant by unstable. It simply means that most federal arrangements tend to be characterised by a constant ebb and flow of authority between levels of government (Donahue and Pollack, 2001). This refers not only to policy competences 
but can also include other products of conscious institutional design such as modes of representation, organisation of elections, the relative constitutional authority of executive and legislative organs etc (Ordershook and Shvetsova, 1997). This is not necessarily a negative feature since the federal arrangement may still be durable, despite oscillations in authority across territorial levels. The comparative federalism literature has devoted much intellectual energy into studying what is variously referred to as the sustainability, durability, or the operation of federal safeguards and/or the role of self-enforcing federal institutions (Bednar et al., 2001; Weingast, 1995; Filipov et al., 2004). All refer to the same thing: once agreed upon, the capacity of a federal contract to be self-enforcing so that none of the players, at various territorial levels, oversteps its bounds so as to threaten the viability of the federal polity. The literature identifies a series of safeguards such as the structural division of power between territorial level and central branches, the role of the judiciary, and the evolution of a federal culture (especially Bednar et al., 2001). Some analysts, drawing on the seminal work of Riker (1964), argue that the party system is the key variable (Filipov et al., 2004). In this article we investigate how mechanisms of direct democracy can impact on the federal balance and whether, or under what conditions, they could constitute a safeguard. With these clarifications in place we can move onto the criteria for case selection.

According to Føllesdal (2003), a federal arrangement refers to a political order where 'final authority is divided between sub-units and a center' and in which 'sovereignty is constitutionally split between at least two territorial levels so that units at each level have final authority and can act independently of the others in some area.' This suggests a promising avenue for comparative research on the EU but raises one potential point of controversy: federalism and statehood. The EU is clearly not a state, but, as one eminent scholar of federalism has argued, a federal arrangement need not be coupled with notions of statehood (Elazar, 1987). Such an understanding has spawned a whole research tradition in which the EU is analysed as a federal system. The literature on federalism tends to identify a special category of federations among the so-called advanced democracies. The 'five usual federal suspects', $\mathrm{n}=5$, are Australia, Canada, Germany, Switzerland, and the US. The 'five usual federal suspects' have figured quite prominently in policy studies, although sometimes the federal $n=6$, when Austria is added (e.g. see Keman, 2000; Lijphart, 1984). More problematic is the inclusion of other quasi-federal suspects such as Belgium, Spain and Italy, though these can be referred to as a distinct category of 'regionalised systems' (Braun, 2000). For instance, on the basis of a series of empirical indicators, such as central and sub-unit revenues and expenditures, regional grants from central government, and the strength of bicameralism, Braun (2000) identifies a distinct federal group composed of the 'five usual federal suspects'. There is thus a reasonable degree of consensus in the literature as to this special category of advanced industrial states.

The argument put forward in this article is that it is possible to narrow this federal group further still. This is precisely the logic behind some of the latest comparative federalism scholarship on the EU (Menon \& Schain, 2006). A number of relevant concepts emerge from the literature that essentially refer to the same phenomena: 'compound polity', 'separation of powers federal system', and 'fragmented power federal systems'. We 
shall employ the less wordy concept of a compound polity. The term is used by Fabbrini (2004) to describe a form of political organisation that is characterised by a dual or multiple separations of powers: vertically between the sub-units and the centre; and horizontally in terms of divided institutions. All federal states have a vertical separation of powers between territorial units, although this does not imply they separate power across horizontal institutions. According to Fabbrini (2004), apart from the US, the only other 'compound polity' that exists which is organized around a federal distribution of territorial power and a separation of institutions at the governmental level is Switzerland. However, he then omits the Swiss case to argue that the EU is a compound polity à la US (see also Fabbrini \& Sicurelli, 2004). Having identified the only three existing cases of compound polities, Fabbrini then proceeds to dismiss one of the cases on the grounds of size. The problem with such a line of reasoning is that it logically implies that there must be a certain geographical extension or demographic threshold condition for a compound polity. Incidentally, neither condition actually figures in Fabbrini's operational definition of a compound polity. This may appear even more problematic given that the question of size or scale has not hindered the development of comparative federalism as a field of inquiry. Indeed, one could argue that the field of comparative federalism has developed precisely because it has not taken account of variations in size or scale among states, but rather because it has ignored such variables. This has permitted the fruitful comparison of political dynamics in federations, including large ones such as India and Russia and much smaller ones such as Belgium (Lane and Ersson, 2000). But the more serious objection is a methodological one. As Ragin et al. (1996) have argued there are serious methodological grounds for including all cases of a known but limited universe since the exclusion of any single case may alter the findings.

Kelemen's work on 'separation of powers federal system' also explicitly incorporates the EU to his research design $(2000,2004)$. Kelemen identifies two types of federal polities: 'separation of powers federal systems' and 'parliamentary federal systems'. He includes the US and the EU within the first category (Switzerland could also added), while Australia and Canada fall within the second (Germany could also be added). We can surmise, therefore, that a compound polity is a special class of federal polity that is characterised by a fragmented centre and needs to be distinguished from classic parliamentary federal systems (e.g. Germany, Australia and Canada). In the latter case, the executive and legislature are fused whereas in a compound polity there is clear separation (Kelemen, 2000). Therefore, from a comparative federalism perspective the US, Switzerland, and the EU form a very limited universe of compound polities. Given that the object of our comparative inquiry is to shed comparative light on the EU, we can refer to this as an $n=2+$ EU type of research design (where the 2 refers to the US and Switzerland). What are the implications of this type of institutional setting for investigating political processes, and can any comparative insights be applied to patterns of EU-related direct democracy?

We know that the institutional design of a polity has a significant impact on a host of political processes, for instance, on the way in which elections and parties function or on policy and regulatory styles, to name but a few. Indeed, this is the main contribution of what goes by the name of 'new institutionalism' in political science. Essentially, 
the institutional setting determines political opportunity structures by constraining/ enabling particular courses of action to political agents, thus, producing so-called 'structure-induced equilibria' (Shepsle, 1979; Riker, 1980). In short, institutions matter and we should be able to detect their effects on, say, the policy process or party system. An obvious corollary is that this could be the same for the operation of mechanisms of direct democracy in the EU. Recent comparative research on the EU has shown that with regard to the policy dynamics, compound polities do produce distinctive features in a broad range of policy fields including the environment (Kelemen, 2000), fiscal and monetary policy (McKay, 2005), social regulation (Obinger et al., 2005), and internet policies (Mendez, 2005). What about the nature of political contestation, the party system or the way in which elections and parties function? Clearly, this is an area inextricably connected to our broader theoretical and empirical ambitions for understanding the EU-related referendum experiences.

Over the last two decades the EU has become a much more hotly contested arena for political parties, interest groups and social movements. The rise of EU-related referendum politics is clearly a manifestation of this politicisation. One place to start, therefore, is to examine the nature of political contestation over European integration. Scholarship in this area draws much of its intellectual inspiration from the 1960s research of Lipset and Rokkan (1967) on cleavage structures. Applied to the EU, comparative politics research in this field focuses on the contours of the EU political space. Such research is directly relevant to our empirical inquiry. One contribution to the field, the Hix and Lord model, postulates two dimensions of contestation that shape the European political space: more versus less European integration on one axis, and Left versus Right ideology on the other axis (Hix, 1999; Hix \& Lord, 1997). In the language of Lipset and Rokkan the first dimension is territorial while the second is functional. Hix and Lord's argument is that these axes exist in the EU much in the same way as the territorial and functional cleavages persist in compound polities such as the US and Switzerland (the same can be said for Belgium and Canada) ${ }^{1}$. In this connection Riker, also writing in the 1960s, drew attention to the party system as the main variable intervening between the background social conditions we have just identified and the sustainability of a federation (1964). The more decentralised the party system, the more unlikely a centralised federation would develop. One implication that can be drawn from this is that fragmented horizontal institutions in multi-tiered polities tend to have a considerable impact on the party system (Hix, 1998). Many indices have been compiled for comparative research on the EU and federal party systems that suggest a broad area of homogeneity (Thorlakson, 2005). For instance, the party system tends to be decentralised and less cohesive in compound polities. All of these factors play a crucial role in structuring the European political space, its party system and the nature of political contestation. By extension, it is likely that this will directly impact on EU-related referendum politics. We shall return to these questions below. 


\section{INSERTING DIRECT DEMOCRACY INTO THE FEDERAL EQUATION}

A broad area of homogeneity has been established to narrow our federal universes to three cases. Furthermore, it has been argued that the basic institutional set up of 'compound polities' has important structuring effects on within-polity forms of political contestation in the European political space. Let us now introduce mechanisms of direct democracy more explicitly into the federal equation. What can we learn? The first thing to note is that mechanisms of direct democracy exist in all three polities. At a superficial level, there is some degree of similarity among the cases in terms of the use of mechanisms of direct democracy at the sub-unit level. There is, of course, a considerable degree of variance in the intensity of use and spread at the sub-unit level among the three polities. Nevertheless, the mechanisms are present in one form or other across the cases. At one extreme, a small number of EU member states have a well established tradition of direct democracy (e.g. Italy, Ireland, Denmark) and this may be spreading to some of the recently democratised new member states from Central and Eastern Europe (e.g. Slovenia, Estonia, Lithuania). At the other end of the spectrum, mechanisms of direct democracy are firmly rooted in the political culture of Switzerland and are used across all the sub-units, i.e. the cantons (Linder, 2006). Somewhere in the middle is the US where almost half of the states (24 states) have well established mechanisms of citizen initiatives and referendums (Bowler \& Donavon, 1998; Butler \& Ramney, 1994). ${ }^{2}$ Similar patterns can be found at the sub-sub-unit level in the US where many localities offer these participatory mechanisms (Matsusaka, 2003), and the same is true for EU member states. From comparative perspective Switzerland is, again, an outlier in terms of the practice of direct democracy at the communal level.

Instruments of direct democracy can therefore be considered as well established practices across the three cases although their intensity and spread may vary at the sub-unit level (and lower-level units). When our attention is turned to the federal-level however, a rather different picture crystallises. Here one can clearly distinguish between the US and the EU on one side, and Switzerland on the other. There are no mechanisms for federal-level referendums in the US or in the EU. ${ }^{3}$ With 550 referendums since its foundation as a modern federal state in 1848, Switzerland is clearly an outlier case among federal states in terms of the intensity of its use of federal referendums. By contrast, there are no mechanisms for holding federal level referendums in the EU or the US. This is despite periodic calls for holding a national referendum in the US, a national initiative to be more precise (Magleby, 1998), and similar calls in the EU (de Witte, 2005). In fact, there were serious calls during the drafting of the European Constitution for an EU-wide referendum, but these were eventually shirked by the Presidium that drafted the document (de Witte, 2005).

2 In fact, all US states except for Delaware have a provision for a constitutional referendum for amendments to state Constitutions (see Magleby, 2001).

3 In fact, if we extend our sample to include the other 'usual federal suspects' we find that the same is true for Germany where, largely as a result of the negative Weimer republic experience, referendums are banned at the federal level. Australia and Canada, on the other hand, have had federal-level referendum experiences though this needs to be qualified. The federal referendum tool has rarely been used in Canada (three times in its history), whereas in Australia 49 federal referendums have been held thus far. Further information on the referendums can be obtained at the C2D's database: http:/ /www.c2d.ch 
Based on the analysis above it appears that the EU is closer to the US model. This suggests an important distinction among the three compound polities: the presence or not of federal-level referendums. However, to leave the issue here would be rather premature and ignore a critical element. In the US model, the sub-units are prohibited from undertaking referendums on federal issues. In the Swiss model there are various constitutional mechanisms, some mandatory others optional, for the sub-units to act as a veto point through popular votes on federalisation issues. In the EU case, under special circumstances, the sub-units can also perform this veto role suggesting a functional similarity of sorts among the two compound polities -at least from a bottom-up subunit perspective. There is something clearly anomalous here. This can be expressed in terms of a vertical dimension and a horizontal dimension with reference to federal-level referendums. The differences are presented in table 1.

Table 1. Compound polity models of direct democracy

\begin{tabular}{|c|c|c|}
\hline & $\begin{array}{c}\text { Vertically } \\
\text { Integrated }\end{array}$ & $\begin{array}{c}\text { Vertically } \\
\text { Fragmented }\end{array}$ \\
\hline Horizontally Integrated & $\begin{array}{c}\text { Switzerland } \\
\text { Model 3 }\end{array}$ & $\begin{array}{c}\text { US } \\
\text { Model 2 }\end{array}$ \\
\hline Horizontally Fragmented & $?$ & European Union \\
& Model 4 & Model 1 \\
\hline
\end{tabular}

Table 1 identifies four possible models drawn out from our analysis. In terms of direct democracy models, a compound polity can be vertically integrated or fragmented and, on the horizontal level, also integrated or fragmented. This can be illustrated by examining model 1, the EU. It is characterised by the presence of horizontally fragmented referendum mechanisms across the sub-units on federal-level issues. In other words, some sub units (e.g. Ireland, Denmark or France) hold EU-related referendums while others (e.g. Germany and Greece) do not. On the vertical level the EU is also fragmented meaning that while referendums are used at the sub-unit level, there is no EU level referendum. This last feature is shared by model 2, the US case. In terms of direct democracy models, the US is vertically fragmented since there is no federal-level referendum although these mechanisms exist at the sub-unit level. However, when we turn to the horizontal level we find that the US is horizontally integrated at the sub-unit level on federal issues. This simply means that no sub-unit (individual state) can undertake a referendum on federal issues. In model 3, the Swiss case, there are vertically integrated mechanisms that exist in the form of a federal level referendum (as well as sub-unit level referendums on cantonal issues). Furthermore, the presence of vertically integrated referendum mechanisms also implies a horizontal homogeneity across the sub-units on federal level issues since all the sub-units are required to vote. We refer to this as horizontally integrated mechanisms 
of direct democracy. The existence of integrated vertical and horizontal mechanisms of direct democracy is simply another way of defining what is commonly understood as a federal referendum. The question mark in model 4 identifies a theoretical construct for which there appears to be no known empirical case -at least with regard to our sample of the three compound polities or indeed a larger sample of federal cases.

We can now relate our analysis back to the discussion in section 3 concerning federal safeguards or the durability/sustainability of federal institutions. It would be possible to conclude that both model 2 (the US) and model 3 (Switzerland) offer examples of what historically appear to be sustainable compound polity models of direct democracy. Thus, for Switzerland federal level direct democracy mechanisms could be said to constitute an important institutional safeguard against, for instance, overt centralisation ${ }^{4}$ while, in the US, federal level direct democracy has been consciously avoided. In fact, some legal scholars, using a line of reasoning consistent with the literature on federal safeguards, have argued that direct democracy is to be welcomed at the state/local level and to be avoided at all costs at the federal level (Scharzschild, 2004). What can we say about the EU? One obvious, and potential problem, can be seen by comparing the EU and the US. As discussed above, there is variance across the sub-units in the use of referendum devices in the US and the EU on sub-unit issues. This simply means that some sub-units in the US and EU hold referendums (on state-level issues in the US or member state issues in the EU) while others do not. This need not be a problem so long as the referendums are not on federal-level issues. The potential problem is clearly with regard to federal-level issues. From comparative perspective, therefore, the EU appears to occupy an anomalous position in relation to other compound polity models of direct democracy. This anomaly is characterised by a multiple fragmentation, both vertically and horizontally. Is this necessarily a source of institutional (in)stability, or, could such referendums even be a transient phenomenon. To explore this in greater detail we shall need to take a closer look at the data on the EU-related referendum experience.

\section{CHARTING THE RISE OF DIRECT DEMOCRACY IN THE EU}

In this section we focus on the first question underpinning this article. How have specific mechanisms of direct democracy interacted with the existing federal political institutions of the EU? Although the focus is on the EU, the analysis will still retain its comparative focus. A total of 47 EU-related referendums have been held over the last fifty years. Figures 1-3 show the frequency of votes and the emerging patterns - essentially an increase over the last two decades independently of how we classify the referendums. In many respects, the referendums provide us with a rather neat proxy for the relative politicisation of the EU. For more or less the first 30 years of its history the EU (the EC as it was then called) was a rather low profile affair mostly preoccupied with the technicalities of establishing

4 The interplay of federalism and direct democracy - two of the defining features of Swiss politics- are analysed in detail by Kriesi and Trechsel (2008). 
a customs union and a common market. Incidentally, this is the period where the nationstate reached its apogee and Europe was certainly below most citizens' political radar screen. The literature has sometimes referred to this as the 'permissive consensus', a golden age where citizens appeared to provide elites a free reign on EU matters (Norris, 1997). By the mid-1980s however, a number of externally induced challenges, such as the twin oil shocks, resulted in many member state pursuing divergent responses to the economic fallout and this appeared to be adversely affecting the European economy. Crucially, it provided EU policy elites with the opportunity and justification to put forward a series of federalising measures around a constitutional package referred to as the Single European Act (McKay, 1999). The common market was now effectively reinvented as the internal market' and sold to EU citizens as part of a new liberalising programme set against a psychological deadline, 1992. This process, it could be said, reached its climax with the creation of a single currency, the euro, and the establishment of the European Central Bank in the late 1990s. In this connection, France's 1992 'petit oui' on the Maastricht Treaty, 51 per cent in favour, and Denmark's 'no', ${ }^{5}$ provided some of the first signs of the awakening 'sleeping giant' of political contestation on European issues (van der Eijk \& Franklin, 2004). Indeed, as any student of federalism knows, regulating markets quickly spills-over into other domains.

And so this has been the case with the EU. By the late 1990s a new mobilising agenda centred on establishing an 'area of freedom, security and justice' generated a flurry of policy initiatives in a domain that, in contrast to technical regulatory questions, now touched upon core areas of statehood. The creation of a European Police Office, a European Counter-Terrorism Coordinator, a Joint Situation Centre for coordinating intelligence, or a European External Borders Agency, are just a few examples of the activity in this domain. In a similar vein, the geo-politics of the new post-Cold War order propelled EU policy elites to seek, if not a common policy, then, at least greater coordination in foreign and defence affairs. How else could member states deal with security problems in their own backyards such as the fallout from the dissolution of Yugoslavia? One does not need to be armed with the latest public opinion data to acknowledge that this activity over the last two decades has led to greater political contestation around the European issue (Hooghe et al., 2002). It is no accident, therefore, that this is neatly dovetailed by the activation of increasing EU-related referendum politics as shown in the figures 1-3.

The cursory sketch of EU policymaking patterns over the last fifty years reveal classic patterns of political authority transfer that are familiar terrain to any student of federalism (Donahue \& Pollack, 2001). Indeed, these patterns and processes of federalisation would be immediately recognisable, say, to a Swiss or US constitutional lawyer. Are there any specific constitutional or institutional features that can account for the particular sequencing of EU-related referendums? And, can comparative federalism shed any further light on this matter? Perhaps it can. For instance, we know that political dynamics in federal polities tend to be characterised by a continuous ebb and flow of authority among various levels of public authority and that this can generate high levels of 'constitutional politics' over

5 A 'yes' vote was achieved in 1993, the following year, when the Danes voted for the second time. 
Figure 1: EU-related referendums 1958-2007 (includes non-EU member states)

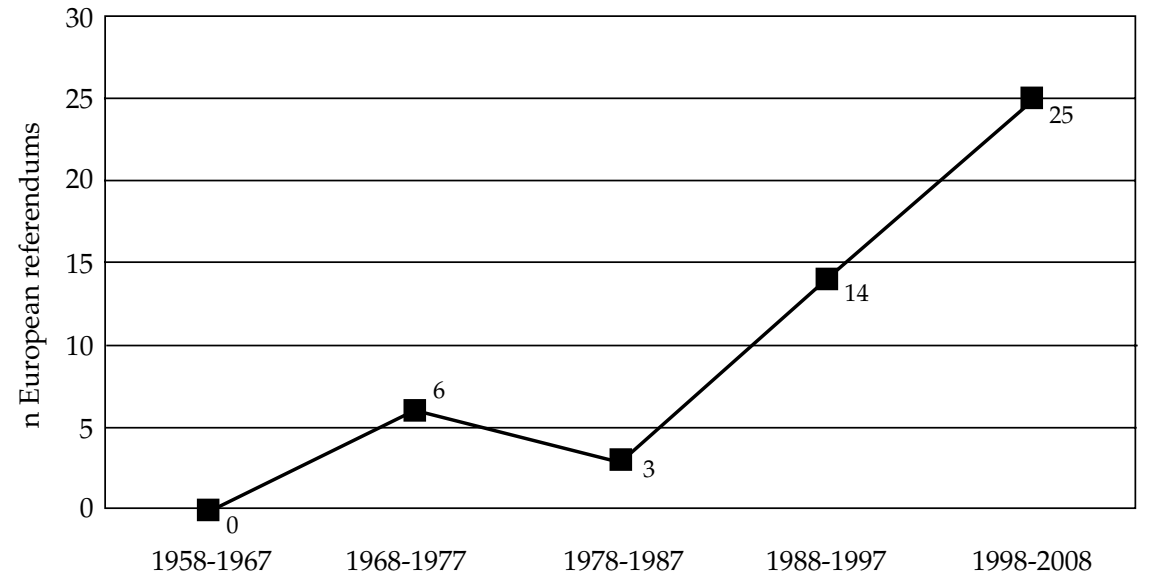

Figure 2: EU referendums of the current $27 \mathrm{EU}$ member states

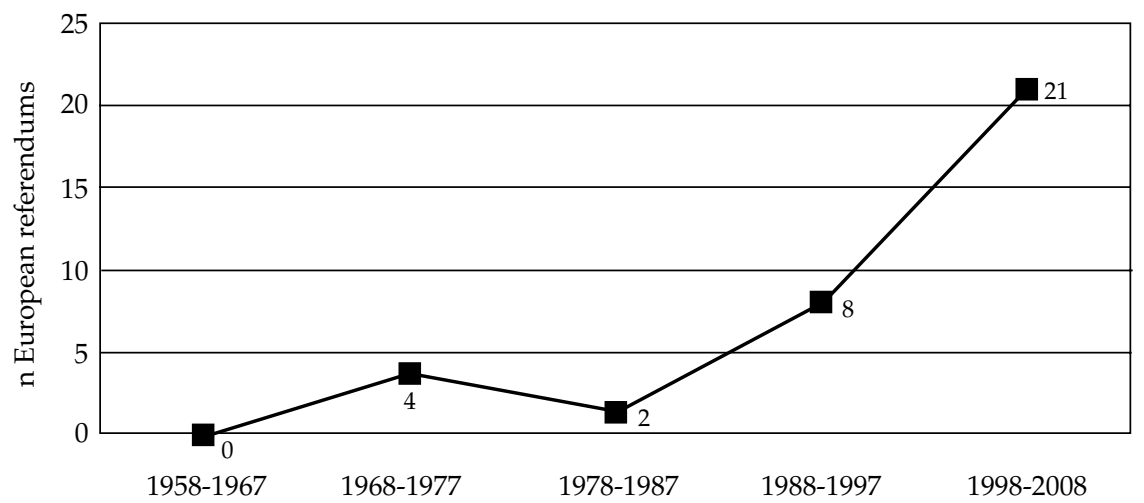

Figure 3: EU polity referendums (excludes non-Member states and Accession referendums)

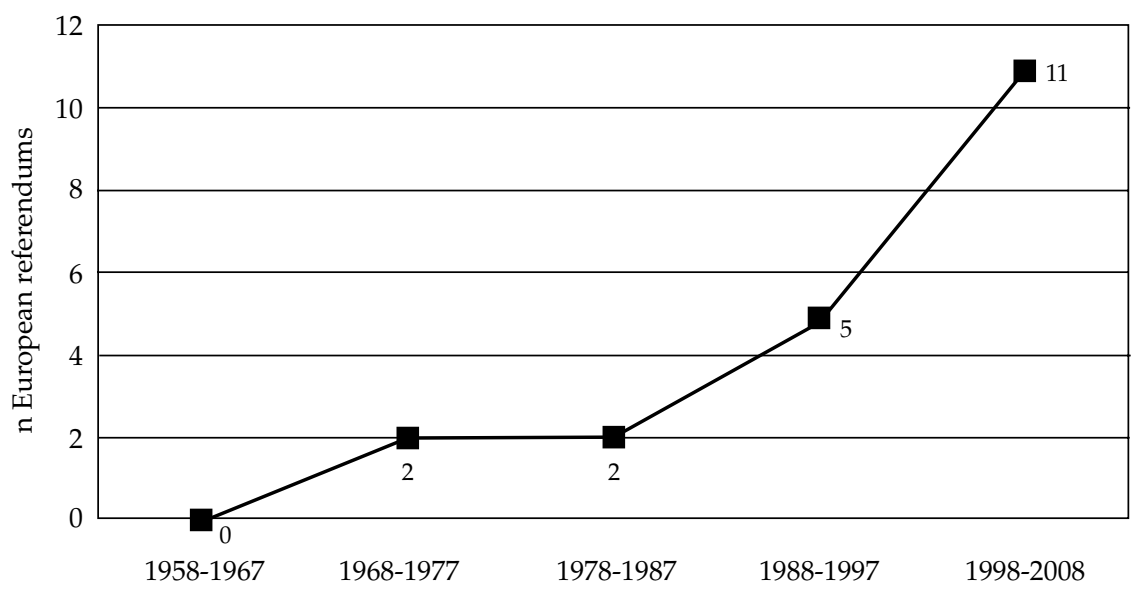


the appropriate vertical allocation of authority (Donahue \& Pollack, 2001). The point is that there are some very important path-dependent reasons for this (Pierson, 2000). Two factors can be especially singled out. First, compound polities, such as the US and Switzerland (to which we add the EU), constitute examples of what Alfred Stepan classifies as 'coming together' types of federalism (1999). This type of polity consists of a coming together of previously distinct units to form a new body politic. Most importantly, these polities tend to be characterised by a fear of excessive central government power and possess institutional arrangements that constrain the centre from overriding the sub-units (Føllesdal, 2003). Second, there are constitutionally codified protections to prevent this from happening. Thus, a common feature of compound polities is that one of the core powers delegated to the centre is the regulation of the market. On the other hand, another common feature of compound polities is that matters related to internal security, for instance, have typically been reserved to the sub-units. None of the foundational constitutional texts in the US, Switzerland, or the EU contained provisions that granted the centre competencies in the field of internal security. Creeping centralisation evolved over time and as a result of intense policy clashes.

There is one last element that needs to be added to this argument. It reveals a difference among the compound polities that helps explain the sequencing of EU-related referendums. Whereas the US has a Constitution with a remarkably concise coverage of loosely framed competences, the lengthy constitutional documents of the EU and Switzerland have much more complex and restrictive catalogues of competencies. This suggests another potential factor at play in accounting for the accretion of powers to the centre: the role of non-majoritarian institutions. In the US, the Supreme Court's role as 'umpire of the federal system' has given rise to periods of both centralisation and decentralisation of power (Scheiber, 2005). In particular, the 1940s to the mid-1990s have been viewed as a period of great accretion of power to the centre, albeit with a recent trend towards greater decentralisation. Similarly, it is well-known that that the European Court of Justice (ECJ) has played a crucial role in the accretion of power to the centre as well as, more generally, in the integration process (the classic accounts are provided by Stein 1981 and Weiler, 1999). It is important to note, however, that this has occurred principally in the initial spheres of EU competence related to the internal market (Weiler, 1999) The point, in this connection, is that the constraining remit of the basic constitutional text in the EU (the same is true for Switzerland) provides much less room for judicial-led accretion of power to the centre outside those areas indispensable to regulating the market. Given the absence of a constitutional peg for judicial centralisation in areas reserved to the subunits, the allocation of new powers to the centre in Switzerland and the EU is achieved through constitutional amendments. These take place via a mandatory referendum vote in Switzerland and, in the EU, via the successive Treaties. By contrast, in the US there has been a great deal of judicial led federalisation for example in matters pertaining to internal security which is not possible in the EU or Switzerland without a constitutional amendment according competence in this area.

The constitutional amendment argument can be seen clearly in the EU case. Whilst the EU was mainly concerned with technical and regulatory matters pertaining to the internal 
market, there was little need for constitutional amendments. The relevant regulatory powers were contained in the foundational constitutional text, the 1957 Treaty of Rome. But, as soon as it was desired to use the EU machinery to address adjacent policy areas in response to external and internal challenges, such as monetary union, internal security or foreign affairs, then constitutional amendments permitting such action would be required. Instead, an explicit constitutional attribution of competence in these sensitive areas would be required through the familiar treaty packages. And, not surprisingly, in view of some of the sensitive areas that these treaties now touched upon, the incentives were ripe for greater politicisation and the activation of EU referendum politics. This accounts for the patterns of EU-related referendums in figures 1-3 above, and, perhaps more importantly, suggests that it will continue to be a feature of EU constitutional politics.

\section{THE FALL OF DIRECT DEMOCRACY? THE EU CONSTITUTION AND ITS SEQUEL(S)}

From a comparative federalism perspective, the patterns and timing of EU-related referendums exhibit features that are not surprising. As the preceding section has argued, there is nothing especially puzzling about their recent proliferation. Still, we are some way from adjudicating between the competing arguments concerning the connection between the rise in the use of referendums and institutional stability. A closer look at the EU's experience with the European Constitution and what we refer to as its sequel(s) may provide us with some further insights. ${ }^{6}$ Could the European Constitution and its sequel(s) represent a critical juncture for EU-related referendum politics? The first thing to note is that for the best part of almost a decade, EU leaders and policy elites have been engaged in an institutional drama of continent-wide proportions. Four European cities can neatly serve as symbolic markers of the process. Laeken, where the initial script was drawn up in 2001, provided the basis for creating a constitutional convention presided by the former French President Giscard D'Estaing. It led us directly to Rome where the European Constitution was ceremoniously signed in 2004. After the French and Dutch rejection the following year, a repackaged version of the Constitution was signed by EU leaders in Lisbon at the end of 2007. In Dublin, six months later, a 'no' result was announced in June 2008 triggering an immediate political crisis. What can we surmise from the institutional saga and can a comparative federalism framework shed any light on the process?

Let us start with Laeken and the resulting constitutional convention. By the time EU elites had decided on this course of action it can be said that the 'sleeping giant' of political contestation on EU matters had been awakened. But what was the rationale behind Laeken in the first place? There is an abundant literature providing 'thick' descriptions of the intricacies of the constitutional convention process (Deloche-Gaudez, 2007; Schönlau, 2007). This need not concern us. We have already noted that the periodic negotiation of

6 The (s) at the end of the singular 'sequel' denotes the fact that at the time of writing we do not know whether there will be a single sequel (i.e. a ratified Reform Treaty) or whether a new Treaty will be drafted. 
constitutional packages is a staple feature of the federalisation process in the EU. The Laeken Declaration and the constitutional convention could therefore be seen from this functional perspective. Alternatively, one could privilege ideational mechanisms as do many constructivist-inspired explanations. Indeed, the importance of ideas and discourses in this initially elite-driven process should not be underestimated. Neither should the novelty and the symbolic significance of the European constitutional convention as a mechanism for further democratisation. Intriguingly, the convention process implicated at least three models of democracy: a representative model (through the appointment of national representatives to the Convention); a deliberative model (through the discussions and forums that were organised involving wider civil society groups); and a direct democracy model (through the referendums that were called for in more than a third of the member states). Clearly, one could draw parallels with similar constitutional conventions processes elsewhere. The most popular default comparison is, of course, with the US Philadelphia Convention (Fabbrini, 2004; Deloche-Gaudez, 2003). Less attention has been paid to the Swiss constitutional convention of 1847 (Trechsel, 2005 is an exception). Yet, as we shall note below, though there were important similarities among the three constitutional convention experiences, crucial differences remained.

Our attention can now be focused more squarely on Rome and the subsequent ratification process of the Constitutional Treaty signed there in 2004. The crucial point is that the choice of ratification mechanisms was left to the sub-units (de Witte, 2005). This was not wholly unprecedented. For instance, the US and Swiss constitutional conventions had done exactly the same. Interestingly, the EU Constitution even contained a Plan B whereby the EU's highest political body, the European Council, would decide on how to proceed if ratification problems were encountered (de Witte, 2005). If after two years of signing the EU Constitution four-fifths of the member states had ratified it and one or more encounter problems then the European Council would step in. So what went wrong? A historical counterfactual could be offered here as a clue. The constitutional convention process in all three cases involved a rejection of the Constitution by some of the sub-units. Nine Swiss cantons rejected the 1848 Constitution as did Rhode Island the US Constitution of 1789. It is not clear that ratification would have proceeded as smoothly as it did if Virginia in the US or, say, Zurich in the Swiss case, had said 'no' as did France in the EU. ' There is no way to prove this or the equally speculative hypothesis that even if the UK had said 'no' a solution may have been found at the European Council level given the high likelihood of such a 'no'. Clearly, it matters politically who says 'no'. Although legally equivalent, there is a political gulf between a French 'no' and an Irish 'no', as elites in the latter case are repeatedly learning.

It should be noted that EU related referendum politics were triggered well before the European Constitution had been signed. Indeed, a domino effect across the member states could be detected. This is not new. For instance, when the EU enlarged to incorporate ten new member states in 2004 a similar referendum domino effect was generated. Between

7 In fact, in the case of the US the imperative that Virginia adopt the new Constitution is highlighted by the 'Connecticut Compromise' which specifically addressed Virginia's outspoken objections. 
March and September 2003 nine of the ten candidate countries put EU accession to a popular vote. But these referendums did not impact on the EU-polity as such - they were external-polity referendums whereas referendums on the European Constitution had within-polity effects. Clearly, there is a difference. Nonetheless, the domino effect is important to note. By the time of the first rejection of the European Constitution, the French 'no', ten member states had announced their plan to hold a popular vote. This was certainly not expected. A critical juncture was no doubt the British Prime Minister's unexpected decision to promise a referendum. The French President's decision followed days later. Both decisions were taken by political leaders under intense pressure within their own parties and from opposition parties. There is a lively scholarly debate on the ratification process and why some member states opted for a popular vote while others chose the parliamentary route. Usually it involves pitting rational choice against ideational explanations (see Closa 2007 for a review). Clearly elements of both the logic of calculation and the logic of appropriateness were at play here (Hall \& Taylor, 1996). In some cases, the explanation is much more straightforward. Germany, for instance, is constitutionally prohibited from holding a referendum though this did not prevent some political forces from calling for one. The French 'no', followed by the Dutch 'no' a few days later, appeared to seal the fate of the European Constitution ceremoniously signed in Rome seven months earlier.

But the European Constitution did not go away - too much political capital had already been invested. Besides, EU elites believed that without many of the institutional changes the EU political machinery would grind to a halt. Thus, after allowing citizens their say and politely listening for a period, EU political elites retook the driving seat and pursued what became the Lisbon route. The trauma of the French and Dutch 'no' triggered a number of elite reactions two of which are worth mentioning. The first to come, literally days after the two referendum votes, was the call by the European Council for a 'period of reflection'. In parallel, the European Commission launched its Plan D (Democracy, Dialogue, Debate) which was supposed to lay the foundations for the profound debate about Europe's future. The period of reflection conveniently lasted until January 2007 when Germany took charge of the EU presidency. Only a political heavyweight such as Germany under the leadership of Merkel could resuscitate the European Constitution. Much political wrangling took place as the delicate compromise signed in Rome began to unravel. The negotiations reached a climax with a German and Polish confrontation over voting rights in mid-2007. In the end a compromise was achieved and the new Treaty was to be signed at Lisbon six months later. Rome was reinvented as Lisbon. However, the latter had some of the overt constitutional symbols removed and included a host of inelegant opt-outs, and special protocols. Can any comparative insights be drawn? Actually they can. As noted in the previous section, federal systems are characterised by a frequent need to adjust their constitutional text -whether by express amendment or judicial interpretation- to deal with internal and external challenges. Where powers not explicitly delegated to the centre are reserved to the sub-units, as in Switzerland and the US, federalisation will involve periodic constitutional adjustment. Admittedly, constitutional amendments in the US have been few and far between with only twenty-seven thus far, many of which took place in the immediate aftermath of the initial signing the Constitution. Instead, it has been the Supreme Court 
that has played the crucial role in adapting existing constitutional provisions to internal and external challenges. Switzerland's detailed and codified Constitution of 1848, however, was soon in need of revision. In part propelled by a new wave of democratisation at the Cantonal level during the mid-1860s and the need for new competencies for the centre, a revised Constitution was proposed by the executive in 1871 and put to the people the following year (Lehmbruch, 1993). Intriguingly, like the European Constitution it failed. In fact, it was perceived as too centralising, especially by the French-speaking part. As with Lisbon, a repackaged version was negotiated and resubmitted to the people three years later. The difference, of course, is that the new package was accepted by the Swiss people in 1874. It is important to note that as compensation for a certain degree of federalisation, the newly revised Swiss Federal Constitution of 1874 incorporated novel mechanisms of direct democracy, such as the federal legislative referendum, ${ }^{8}$ while the federal level citizens' initiative followed 17 years later in 1891.

Another major difference between the Swiss and EU example is that the former had overcome the unanimity constraint (Trechsel, 2005). In the EU case, in other words, constitutional revision involves unanimity among the sub-units. Thus, while there were parallels in terms of re-submitting a constitutional document to the people important procedural difference remained. Trechsel (2005) has referred to this unanimity constraint as the 'federalist deficit'. In principle, it need not be. In fact, unanimity might not have mattered if ratifying Lisbon would have proceeded through the parliamentary route. The period of reflection had provided EU elites with a unique opportunity to try and neutralise the referendum threat by agreeing on a parliamentary ratification procedure that would avert a popular vote. There was one problem however. Ireland, one of the smallest EU member states with a mere 0.8 per cent of the EU population, has a mandatory referendum provision for amendments to its Constitution ensuring that the Reform Treaty had to be submitted to a popular vote.

As with the European Constitution, the fact that Dublin would hold a popular vote on the Lisbon Treaty triggered a domino effect of referendum politics across the EU. By referendum politics on the Lisbon Treaty we refer to politicisation of the issue -whether or not to hold a referendum- within and across the member states. This was particularly acute in some member states such as the UK and The Netherlands. In others, politicisation took slightly different forms. Since a referendum is prohibited at the federal level in Germany, opposition has taken the form of constitutional challenges. It is not the first time either, the same happened with the 1991 Maastricht Treaty. A similar dynamic has occurred in the Czech Republic where the Constitutional Court will decide on the compatibility of the Lisbon Treaty with its domestic constitutional order. ${ }^{9}$ In the end it was Ireland that submitted the constitutional package to a popular vote and Dublin that announced the 53 per cent vote against the Lisbon Treaty in June 2008. It is clearly too early to tell what will happen to Lisbon after the Irish 'no'. A

$8 \quad$ Citizens could oppose a federal law within 100 days of its official publication. It was followed in 1891 by the introduction of the citizens' initiative at the federal level.

9 In the UK context, the High Court in June 2008 rejected a constitutional challenge arguing for a referendum on the Lisbon Treaty and an attempted appeal was rejected by the Court of Appeal in July 2008. 
few pointers, however, can be offered. The reaction of the European Council is illustrative in this regard. Whereas it called for a 'period of reflection' after the French and Dutch 'no', in the aftermath of Dublin it reached a very different conclusion. The ratification process was to continue as planned and the Irish, in the meantime, would decide what to do next and duly inform their colleagues at the next scheduled summit. ${ }^{10}$ Many EU elites are hoping that the Irish will re-submit Lisbon to a popular vote as they did when the Nice Treaty was rejected in 2001. This may be a tall order however. Whether this happens or not, perhaps we have reached a critical juncture marking the beginning of the fall of EU-related direct democracy? This question is explored below.

\section{FOUR COMPOUND POLITY MODELS OF DIRECT DEMOCRACY}

The institutional wrangling during the last decade over negotiating a new constitutional settlement for the EU suggests that the current variant of direct democracy is problematic. If the analysis of the European Constitution and its sequel(s) is broadly correct, this does not appear to support the stability inducing argument. Our comparative analysis has suggested an institutional configuration where this could, however, be achieved. If, for instance, the EU were to move towards a Swiss variant then it is conceivable that member state referendums on EU level issues could be added to the list of structural safeguards that the literature on comparative federalism identifies. The plausibility of such a move is explored below. However, there is another option that would undermine the instability thesis. Could the European Constitution and its sequel(s) represent a critical juncture marking the fall of direct democracy? This would entail that EU elites have sufficiently learnt from the episode to be able to avoid the national referendum trap. While theoretically plausible there are good reasons to believe that this is wishful thinking. To show why, we shall need to return to the four compound polity models of direct democracy. Table 2 represents the different institutional configurations for accommodating the tensions generated between federalism and direct democracy (to which we have added a label for model 4). We can now explore the range of variance on our dependent variable -EU institutional stability-by examining the plausibility of each compound polity model of direct democracy for the EU.

Table 2. Compound polity models of direct democracy

\begin{tabular}{|c|c|c|}
\hline & $\begin{array}{c}\text { Vertically } \\
\text { Integrated }\end{array}$ & $\begin{array}{c}\text { Vertically } \\
\text { Fragmented }\end{array}$ \\
\hline Horizontally Integrated & Switzerland & US \\
& Model 3 & Model 2 \\
\hline Horizontally Fragmented & Variable Geometry & $\begin{array}{c}\text { European Union } \\
\text { Model 1 }\end{array}$ \\
& Model & Model \\
\hline
\end{tabular}


Let us recall the features of model 1, the EU compound polity variant of direct democracy. It is characterised by multiple fragmentation: both vertically fragmented (in terms of the absence of federal level referendums) and horizontally fragmented (in terms of variation among the sub-units on the use of referendums on federal-level issues) mechanisms of direct democracy. From comparative perspective, this appears unsustainable. Why should this be the case? Our comparative federalism lens has suggested that compound polities are characterised by particular patterns of federalisation. For instance, in charting the rise of within polity EU referendums (figures 1-3) we saw that the frequency of referendums neatly dovetail the proliferation of the familiar federalisation packages we call EU Treaties. The need for these periodic constitutional readjustments is deeply rooted in the legal architecture of compound polities. In particular, where detailed constitutional texts exist, such as those of Switzerland and the EU, the need for frequent constitutional amendments and/or revisions to the constitution is likely to be high. Unless the current Lisbon package (or its sequel) definitively resolves questions of institutional balance, this pattern will continue to persist. And it is here where the specific interplay of federal political institutions and mechanisms of direct democracy is activated. In fact, this was the principal justification for analysing the referendum politics around the European Constitution in more depth. What can we deduce from this? To briefly answer this and relate it to our models we need to refocus on the nature of political contestation in the EU.

In section 2 we noted two dimensions of political contestation that are typical of compound polities, one territorial (more or less European integration) and the other functional (left/ right ideology). However, when we look at existing forms of representation in the EU a rather dysfunctional picture emerges that is inextricably connected to EU referendum politics. Two channels of representation exist, European Parliament elections and member state elections. The EU's constitutional architecture is presently structured in such a way that the European Parliament has an impact on the functional dimension, i.e. over the nature of EU policy outputs. Authority with regard to the territorial dimension (more/less European integration), however, rests with the member states. Reflecting on this problem, Peter Mair has argued that the EU is largely depoliticized as a result of the deliberate strategy of elites who are reluctant to be constrained by popular democracy (Mair, 2007). Thus, EU elites have depoliticised the EU issue from member state elections, where it presently matters, and competed on the Europeanisation issue (more/less integration) during European Parliamentary electoral contests, where it is largely irrelevant. The cumulative impact, according to Mair (2007), is that citizens are not offered channels for the legitimate expression of opposition in principle to the EU, and, because citizens are denied a political arena in which to contest Europe, they are propelled into opposing the EU polity as a whole. The politicisation around EU-related referendums can be understood as a manifestation of this dynamic, i.e. the absence of institutionalised mechanisms of opposition to the EU.

The importance of legitimate political opposition as a central component of liberal democracy, has been repeatedly emphasised by one of the foremost scholars of democracy, Robert Dahl (see also Stepan, 1990; Kirchheimer, 1957). Although there is a comparative politics literature on models of opposition, these usually take the classic parliamentary or 
Westminster models as the true model (for reviews see Helms, 2004; Blondel, 1997; von Beyme, 1987). However, this model of parliamentary opposition clearly does not apply to our sample of compound polities. While the US pattern of opposition is commonly understood to take the form of congressional opposition to the presidency (or vice versa), the Swiss case appears to be characterised by the absence of institutionalised opposition (Helms, 2004; Rose, 2000; Glass, 1978). In the latter case, all major political forces are represented in a federal-level grand coalition that does not risk, according to Richard Rose, the purgatory of opposition (Rose, 2000). Obviously, the type of electoral system (e.g. proportional versus majoritarian) matters here. Nonetheless, in terms of models of opposition, unlike the US model the Swiss system does not possess mechanisms for voters to express their dissatisfaction with governing parties and 'kick the rascals out' of office (on the US/EU see Føllesdal \& Hix, 2006). Clearly, mechanisms of opposition do exist in Switzerland though these take a special form. This has been categorised as the 'direct democratic model of political opposition' (Helms, 2004). In other words, mechanisms of direct democracy are the institutional channel through which the function of opposition is performed. Furthermore, these channels have been at the centre of political competition over the 'territorial' cleavage. Perhaps there are lessons to be drawn here with regard to the EU. Some were identified in the analysis of the referendum politics of the European Constitution and its sequel(s) in section 5 . In the absence of other channels to mobilise against the EU, political opposition to the EU has seized, where available, the tool of subunit referendums on federal level issues to express anti-federalisation preferences. Are such preferences likely to disappear? If comparative politics has any insights to offer the answer is definitely 'no'. What, then, are the options for the EU?

If model 1 is unsustainable what are the possibilities for an EU move towards model 2 for which the US can be considered as a prototype. This move appears the most straightforward in many respects. It merely implies two things: first no EU level referendum and, second, no member state referendums on EU issues. The first element is easy to address since it does not exist. The second presents a number of problems however. Essentially, it involves banning sub-unit referendums on EU-level issues. There are two ways of trying to achieve this, one informal the other more formal. The informal route was tried during the Lisbon process. After the rejection of the European Constitution, EU elites colluded in neutralising the referendum threat by ensuring that member states pursued a parliamentary ratification rather than a popular vote. This heroic coordination effort is not to be underestimated, but, as the argument above suggests, it is unlikely that this could ever be repeated, especially if the 'sleeping giant' of European political contestation has finally awoken. Besides, it did not work. Ireland voted no.

The second option, the formal route, would involve prohibiting member states from undertaking referendums on EU issues. Some clarification of what is meant by EU issues is in order. Here, we are referring to referendums on the familiar EU treaties, what Andreas Auer (2007) has labelled 'integration referendums' as opposed to what he calls an 'accession referendum'. The latter includes referendums on adopting, say the Euro currency. Thus, a referendum by a sub-unit on acceding, say to the Eurozone, is legitimate since the consequences are only felt within that sub-unit rather than the polity 
as a whole. ${ }^{11}$ We can already begin to see the legal minefield that this could open up. Furthermore, historically, EU treaties have bundled 'accession' and 'integration' issues into a single constitutional package (e.g. the Maastricht Treaty). Still, in principle it is possible that the two could be distinguished resulting in the constitutional prohibition of sub-unit referendums on so-called EU 'integration referendums'. How could this be achieved? For a start at least three member states, Ireland, Denmark and France would have to change their Constitutions. Even if this were feasible, which we believe it is not, it would still leave unanswered the root problem: an absence of effective participatory or input-oriented democratic instruments on EU issues. Member state executives would continue to do business as usual at the grand summits and decide on the future pace of integration. As we have argued above, while summits dealt with technical regulatory issues this was fine, but as soon as the focus shifts to, say justice and internal security issues, or foreign and defence affairs, politicisation occurs. If our political elites cannot be trusted, then, how about putting our trust in non-majoritarian institutions? This question opens a curious option, the German model. It is functionally equivalent to the US model, i.e. federal level referendums do not exist and neither can the sub-units undertake popular votes on federal issues. How, then, do they resolve the inevitable tensions that may arise? The Lisbon Treaty (and the earlier Maastricht Treaty) gave us a glimpse of the model. In the absence of mechanisms of popular consultation, political opposition has taken to the Courts. Thus, the decision is left to a non-majoritarian institution, the German Federal Constitutional Court. This is not a model that can be replicated at the EU level however. The ECJ can hardly be constitutionally empowered to pronounce on whether a new federal level constitutional framework, such as was provided by the Constitution or now the Lisbon Treaty, is compatible with the present constitutional framework.

If a move towards model 2 looks fraught with difficulties, how about model 3 for which Switzerland can be considered as a proto-type? A move in this direction has, in fact, already been taken. Article I-47 of the European Constitution included provisions for an EU-wide citizens' initiative requiring the collection of 1 million signatures across EU member states for requesting that the Commission propose EU legislation. Furthermore, despite the rejection of the European Constitution, the same provision was kept in the Lisbon Treaty under Article 8b. Does this suggest any parallels with the introduction of the citizens' initiative at the federal level in Switzerland? We know from the Swiss case, for instance, that the introduction of such an innovation had unanticipated consequences by providing new channels for mobilising political opposition (Lehmbruch, 1993). We also know from our discussion that the EU suffers from the absence of participatory channels for mobilising political opposition in the EU. Nonetheless, the comparison should not be pushed too far. Without downplaying the significance of the instrument (for instance the US has not implemented one despite numerous calls), the EU variant of bottomup direct democracy is really a petition rather than a full-blown citizens' initiative a la Suisse. Still, as this discussion suggests, if implemented it could have unintended political

11 The same applies to a referendum on enlargement by one of the sub-units, e.g. a vote by France on Turkey joining the EU. 
effects. However, the focus of this article has not been on bottom-up mechanisms of direct democracy such as citizens' initiatives. Instead, the defining feature of model 3 is a federal level referendum. Here, the potential for an EU-wide referendum would constitute a revolutionary act of considerable proportions. For a start, it would only make sense if the unanimity principle were overcome. In other words, some super-majoritarian threshold would have to be instituted for it to have any functional utility. It seems that, much like banning member state referendums on EU integration, and perhaps even more so, a revolutionary act of this nature seems quite implausible at this particular juncture. The full repertoire of Swiss direct democracy instruments is clearly not feasible for the EU, as the EU version of the citizens' initiative demonstrates, though some less institutionalised variants could perhaps emerge over time.

If variants of US model 2, or Swiss model 3, are presently implausible what of model 4, the variable geometry model. There has been much talk of variable geometry or a Europe of two speeds. Could such a model be applied to EU-related referendums? In essence, variable geometry involves an inner core of the sub-units pushing ahead with integration while an outer core either waits until it can overcome domestic political constraints should it wish to join or simply does not join because it is not convinced of the benefits. Indeed, there are constitutional mechanisms, known as 'enhanced cooperation', that allow a select group of member states (at least eight) to push ahead in a given policy domain using the EU machinery (Bribosia, 2007). The problem is that these provisions relate to particular policy fields rather than a polity's basic constitutional architecture. If the Lisbon Treaty starts to unravel, then variable geometry may become a reality even for the EU's basic constitutional architecture. Let us examine this theoretical construct further with regard to EU-related referendums. The lower left box suggests the presence of vertically integrated referendum mechanisms, i.e. an EU-level referendum, but with horizontally fragmented mechanisms at the sub-unit level, i.e. variation among the member states with regard to referendums on EU integration issues (as is presently the case). This sounds bizarre. How would it work? Essentially, some variant of 'enhanced cooperation' could be used to institute a vertically integrated referendum for an inner core of member states. These sub-units could submit further federalisation packages to a popular vote across the innercore in the same way referendums are held in Switzerland or Australia. However, the outer-core would not be subject to this procedure, hence the horizontal fragmentation. In a way there are already precedents for this, such as the eurozone for monetary matters and Schengen for certain justice and home affairs issues. The crucial point is that decisionmaking in these areas is presently not subject to a popular vote, neither is it likely to be. The variable geometry model represents a legal nightmare, but then the EU as a polity is no stranger to this. Still, the model appears rather implausible and is pursued here for mainly theoretical purposes. The logic of this variable geometry could also be inverted. This is probably more plausible and legally more elegant. In this case, the sub-units forming the inner-core would formally agree not to hold EU integration referendums. Functionally speaking, this would take us from model 4 towards model 2.

So, where have we ended up? At first sight it may appear that the comparative route has led us to an unsatisfactory end destination. Although we have steadfastly followed the 
comparative track to analyse compound polity models of direct democracy, we are unable to adjudicate between the competing models in relation to the EU, especially models 2 and 3. This is not unrelated to the fact that the process we have analysed is at an embryonic stage. Nonetheless, the comparative method has allowed us to isolate some institutional features that are linked to particular outcomes and this has revealed some novel insights about the EU. In doing so, we have used the comparative perspective to show: first, how direct democracy and federalism interact in the EU case and to explain why EU-related referendum politics have arisen at a given temporal juncture; and, second, to try and demonstrate why we believe model 1 is unsustainable while pointing to possible alternative institutional trajectories. Furthermore, we have shown that the problem appears to be rooted in the existence of a peculiar variant of vertically and horizontally fragmented mechanisms of direct democracy. In concluding, it is important to distinguish the instability thesis put forward here from the claim that the EU is suffering from an institutional crisis. As EU scholars have reminded us (e.g. Moravscik, 2005; Kelemen, 2007; Wallace, 2007), in terms of a number of criteria such as policy outputs or even enlargement, the EU is still performing rather well. Thus, the current institutional wrangling might stabilise around a more durable constitutional settlement. But, even if it does, this is still likely to leave unresolved the EU's direct democracy dilemma at the core of this article's analysis.

\section{REFERENCES}

Albi, Anneli and Ziller, Jacques. 2007. The European Constitution and National Constitutions: Ratification and Beyond, Netherlands: Kluwer Law International.

Auer, Andreas. 2005, “Adoption, Ratification and Entry into Force", European Constitutional Law Review, 1(1): 131-135.

2007. "National Referendums in the Process of European Integration: Time for Change", in Albi, Anneli and Ziller, Jacques (ed.), The European Constitution and National Constitutions: Ratification and Beyond (261-271), Netherlands: Kluwer Law International.

Auer, Andreas and Flauss, Jean-François. 1997. Le Référendum Européen, Brussels: Bruylant.

Bednar, Jenna, Eskridge, William Jr. and Ferejohn, John. 2001, "A Political Theory of Federalism", in Ferejohn, John, Rakove, Jack N. and Riley, Jonathan (ed.), Constitutional Culture and Democratic Rule (223-270), New York: Cambridge University Press.

Blondel, Jean. 1997. "Political Opposition in the Contemporary World", Government and Opposition, 32 (4): 462-486.

Bogdanor, Vernon. 1994. "Western Europe”, in Butler, David and Ranney, Austin (ed.), Referendums Around the World. The Growing Use of Direct Democracy (25-97), London: Macmillan.

Bowler, Shawn and Donovan, Todd. 1998. Demanding Choices: Opinion, Voting and Direct Democracy, Ann Arbor: University of Michigan.

Braun, Dietmar. 2000. "The Territorial Division of Power in Comparative Public Policy Research: an Assessment", in Braun, Dietmar (ed.), Public Policy and Federalism (27-56), Aldershot: Ashgate.

Bribosia, Hervé. 2007. «Les coopérations renforcées», in Amato, Giuliano, Bribosia, Hervé and de Witte, Bruno (ed.), Genèse et destinée de la Constitution européenne: Commentaire du Traité établissant une Constitution pour l'Europe à la lumiére des travaux préparatoires et perspectives d'avenir (623-644), Brussels: Bruylant.

Butler, David and Ranney, Austin. 1994. Referendums around the World. The Growing Use of Direct Democracy, Washington: Macmillan - American Enterprise Institute for Public Policy Research. 
Carey, Sean. 2002. "Undivided Loyalties: Is National Identity an Obstacle to European Integration?", European Union Politics, 3(4): 387-413.

Christin, Thomas, Hug, Simon and Sciarini, Pascal. 2002. "Interests and information in referendum voting: an analysis of Swiss voters", European Journal of Political Research, 41 (6): 759-776.

Closa, Montero Carlos. 2007. "Why convene referendums? Explaining choices in EU constitutional politics", Journal of European Public Policy,14 (8): 1311-1332.

de Witte, Bruno. 2005. "The Process of Ratification and the Crisis Options: A Legal Perspective", in Curtin, Deirdre, Kellermann, Alfred. E. and Blockmans, Steven (ed.), The EU Constitution: The Best Way Forward? (21-38), The Hague: TMC Asser Press.

Deloche-Gaudez, Florence. 2007. «La Convention européenne sur l'avenir de l'Europe: ruptures et continuités», in Amato, Giuliano, Bribosia, Hervé and de Witte, Bruno (ed.), Genèse et destinée de la Constitution européenne: Commentaire du Traité établissant une Constitution pour l'Europe à la lumiére des travaux préparatoires et perspectives d'avenir (47-86), Brussels: Bruylant.

2003. «Bruxelles-Philadelphie. D'une Convention à l'autre», Critique Internationale, 3 (21): $135-150$.

Donahue, John D. and Pollack, Mark. A. 2001. "Centralisation and its Discontents: the rhythms of federalism in the United States and the European Union", in Nicolaidis, Kalypso and Howse, Robert (ed.), The Federal Vision: Legitimacy and Levels of Governance in The US and the EU (73-117), Oxford: Oxford University Press.

Elazar, Daniel J. 1987. Exploring Federalism, Tuscaloosa: University Alabama Press.

Fabbrini, Sergio. 2004. "Transatlantic constitutionalism: Comparing the United States and the European Union", European Journal of Political Research, 43 (4): 547-569.

Fabbrini, Sergio and Sicurelli, Daniella. 2004. "The Federalisation of the EU In The Light of the 'Compound Republic Theory': the convention's debate", Regional and Federal Studies, 14 (2): 232-254.

Føllesdal, Andreas. 2003. Stanford Encyclopedia of Philosophy: Federalism, Available at: http:/ / plato.stanford. $\mathrm{edu} / \mathrm{entries/federalism/.}$

Føllesdal, Andreas and Hix, Simon. 2006. "Why There is a Democratic Deficit in the EU: A Response to Majone and Moravcsik", Journal of Common Market Studies, 44 (3): 533-562.

Franklin, Mark. 2002. "Learning from the Danish case: A comment on Palle Svensson's critique of the Franklin thesis", European Journal of Political Research, 41 (6): 757-757.

Franklin, Mark, Marsh, Michael and McLaren, Lauren. 1994. “Uncorking the bottle: popular opposition to European unification in the wake of Maastricht", Journal of Common Market Studies, 32 (4): 455-472.

Glass, Harold. E. 1978. "Consensus and Opposition in Switzerland: A Neglected Consideration", Comparative Politics, 10 (3): 361-372.

Hall, Peter and Taylor, Rosemary. 1996. "Political science and the three new institutionalisms", Political Studies, 44 (5): 936-957.

Helms, Ludger. 2004. "Five Ways of Institutionalizing Political Opposition: Lessons from the Advanced Democracies", Government and Opposition, 39 (1): 22-54.

Hix, Simon. 1999. "Dimensions and alignments in European Union politics: Cognitive constraints and partisan responses", European Journal of Political Research, 35 (1): 69-106.

1998. "Elections, parties and institutional design: A comparative perspective on European Union democracy", West European Politics, 21 (3): 19-52.

Hix, Simon and Lord, Christopher. 1997. Political parties in the European Union, Basingstoke: Macmillan.

Hooghe, Liesbet and Marks, Garry. 2005. "Community, Calculation and Cues", European Union Politics, 6 (4): 421-445.

Hooghe, Liesbet, Marks, Garry and Wilson, Carole. J. 2002. “Does Left/Right Structure Party Positions on European Integration?", Comparative Political Studies, 35 (8): 965-989.

Hug, Simon. 2002. Voices of Europe. Citizens, Referendums and European Integration, New York: Rowman \& Littlefield.

Hug, Simon and Sciarini, Pascal. 2000. "Referendums on European Integration", Comparative Political Studies, 33 (1): 3-36.

Kelemen, R. Daniel. 2004. The Rules of Federalism: Institutions and Regulatory Politics in the EU and Beyond, Cambridge, MA: Harvard University Press. 
2000. "Regulatory federalism: EU environmental policy in comparative perspective", Journal of Public Policy, 20 (2): 133-167.

2007. Built to Last? The Durability of EU Federalism? In Making History: State of the European Union, Vol. 8, (ed) Sophie Meunier and Kate McNamara, Oxford: Oxford University Press,

Keman, Hans. 2000. "Federalism and Policy Performance", in Wachendorfer-Schmidt, U. (ED.), Federalism and Policy Performance (196-227), London: Routledge.

Kirchheimer, Otto. 1957. "The Waning of Opposition in Parliamentary Regimes”, Social Research, 24 (2): 127-156.

Kriesi, Hanspeter and Trechsel, Alexander. 2008. The Politics of Switzerland: Continuity and Change in a Consensus Democracy, Cambridge: Cambridge University Press.

Lehmbruch, Gerhard. 1993. "Consociational Democracy and Corporatism in Switzerland", Publius, 23 (2): 43-60.

Lemco, Jonathan. 1991. Political Stability in Federal Governments, New York: Praeger Publishers.

Lijphart, Arend. 1984. Democracies: Patterns of Majoritarian and Consensus Government in Twenty-One Countries, New Haven: Yale University Press.

Linder, Wolfgang. 2006. "Direct Democracy", in Papadopoulos, Ioannis et al. (ed.), Handbook of Swiss Politics, Zurich: NZZ Publishing.

Lipset, Seymour Martin and Rokkan, Stein. 1967. Party Systems and Voter Alignments: Cross-National Perspectives, New York: The Free Press.

Magleby, David B. 2001. Direct Legislation: Voting on Ballot Propositions in the United States, Baltimore: Johns Hopkins University Press.

1998. "Ballot Initiatives and Intergovernmental Relations in the United States", The Journal of Federalism, 28 (1) 147-163.

Mair, Peter. 2007. "Political Opposition and the European Union", Government and Opposition, 42 (1): 1-17. 2004. "The Europeanization Dimension", Journal of European Public Policy, 11 (2): 337-348.

Majone, Giandomenico. 2005. Dilemmas of European Integration: The Ambiguities and Pitfalls of Integration by Stealth, Oxford: Oxford University Press.

Marks, Garry, Wilson, Carol. J. and Ray, Leonard. 2002. “National political parties and European integration”, American Journal of Political Science, 46 (3): 585-594.

Matsusaka, John. 2003. "The Initiative and Referendum in American Cities: Basic Patterns", in Waters M. Dane (ed.), The Initiative and Referendum Almanac: A Comprehensive Reference Guide to Citizen Lawmaking around the World, Durham, NC: Carolina Academic Press.

McKay, Daniel. 2005. "Economic logic or political logic? Economic theory, federal theory and EMU", Journal of European Public Policy, 12 (3): 528-544. 1999. Federalism and European Union: A Political Economy Perspective, Oxford: Oxford University Press.

McLaren, Lauren. 2002. "Public Support for European Integration: Cost/Benefit Analysis or Perceived Cultural Threat", Journal of Politics, 64 (2): 551-566.

Mendez, Fernando. 2005. "The European Union and cybercrime: insights from comparative federalism", Journal of European Public Policy, 12 (3): 509-527.

Menon, Anand and Schain, Martin. 2006. Comparative Federalism: The European Union and the United States in Comparative Perspective, Oxford: Oxford University Press.

Moravcsik, Andrew. 2006. "What Can We Learn from the Collapse of the European Constitutional Project?", Politische Vierteljahresschrift, 47 (2): 219-241.

Norris, Pipa. 1997. "Representation and the democratic deficit", European Journal of Political Research, 32 (2): 273-282.

Obinger, Herbert, Leibfried, Stephan and Castles, Francis. G. 2005. “Bypasses to a social Europe? Lessons from federal experience", Journal of European Public Policy, 12 (3): 545-571.

Ordeshook, Peter and Shvetsova, Olga. 1997. "Federalism and constitutional design", Journal of democracy, 8 (1): $27-42$.

Pernice, Ingolf. 2006. «Réferendum sur la Constitution pour l'Europe: conditions, risques et implications», in Kaddous, Christine and Auer, Andreas (ed.), Les principes fondamentaux de la Constitution européenne (301-315), Genève: Helbing \& Lichtenhahn. 
2003. "Rethinking the methods of dividing and controlling the competencies of the Union", in Andenas, Mads and Usher, John (ed.), The Treaty of Nice and Beyond: Enlargement and Constitutional Reform (121-145), Oxford: Hart Publishing.

Pierson, Paul. 2000. "Increasing Returns, Path Dependence, and the Study of Politics", The American Political Science Review, 94 (2):251-267.

Ponzano, Paolo, Ziller, Jacques and Pii, Samuele. 2007. Un référendum européen pour la Constitution européenne: problémes juridiques et politiques, Florence: European University Institute (Policy paper (Robert Schuman Centre)) RSCAS PP 2007/01.

Qvortrup, Matt. 2006. “The Three Referendums on the European Constitution Treaty in 2005", The Political Quarterly, 77 (1): 89-97.

2005. A comparative study of referendums: government by the people, (2nd ed.), Manchester: Manchester University Press.

Ray, Leonard. 2003. “When Parties Matter: The Conditional Influence of Party Positions on Voter Opinion about European Integration", Journal of Politics, 65 (4): 978-994.

Riker, William. H. 1980. "Implication from the Disequilibrium of Majority Rule for the Study of Institutions", The American Political Science Review, 74 (2): 432-446.

1964. Federalism: Origin, Operation, Significance, Boston and Toronto: Little, Brown and Co.

Rose, Richard. 2000. "The end of consensus in Austria and Switzerland", Journal of Democracy, 2 (2): 26-40.

Scheiber, Harry N. 2005. "Federalism", in The Oxford Companion to the Supreme Court of the United States (321-332), Oxford: Oxford University Press.

Schneider, Gerard and Weitsman, Patricia A. 1996. “The Punishment Trap: „Integration Referendums as Popularity Contests", Comparative Political Studies, 28 (4): 582-607.

Schönlau, Justus. 2007. "The Convention on the Future of Europe and its Antecedents", in Castiglione, Dario, Schönlau, Justus, Longman, Chris, Lombardo, Emanuela, Pérez-Solórzano, Nieves and Aziz, Miriam (ed), Constitutional Politics in the European Union: The Convention Moment and its Aftermath (51), Palgrave Macmillan.

Setälä, Maija. 1999. "Referendums in Western Europe - A Wave of Direct Democracy", Scandinavian Political Studies, 22 (4): 327-340.

Shepsle, Kenneth. A. 1979. "Institutional Arrangements and Equilibria in Multidimensional Voting Models", American Journal of Political Science, 23 (1): 27-59.

Siune, Karen, Svensson, Palle and Tonsgaard, Ole. 1994. "The European Union: The Danes Said 'No? in 1992 but 'Yes in 1993: How and Why?", Electoral Studies, 13 (2): 107-136.

Steenbergen, Marco R., Edwards, Erica E. and de Vries, Catherine E. 2007. "Who's Cueing Whom? MassElite Linkages and the Future of European Integration", European Union Politics, 8 (1): 13-35.

Stein, Eric. 1981. "Lawyers, Judges and the Making of a Transnational Constitution", American Journal of International Law, 75 (1): 27.

Stepan, Alfred. 1999. "Federalism and democracy: beyond the US model", Journal of Democracy, 10 (4): 19-34. 1990. "On the tasks of a Democratic Opposition", Journal of Democracy, 1 (2): 41-49.

Svensson, Palle. 2007. "Voting Behaviour in the European Constitution Process", in Pallinger, Tiber, Kaufmann, Bruno, Marxer, Wilfried and Schiller, Theo (ed), Direct Democracy in Europe: Developments and Prospects (163-173), Wiesbaden : VS-Verlag.

2002. "Five Danish Referendums on the European Community and European Union: A critical assessment of the Franklin thesis", European Journal of Political Research, 41 (6): 733-750.

1994. "The Danish Yes to Maastricht and Edinburgh. The EC Referendum of May 1993", Scandinavian Political Studies, 17 (1): 69-82.

Thorlakson, Lori. 2005. "Federalism and the European party system", Journal of European Public Policy, 12 (3): 468-487.

Trechsel, Alexander. 2005. "How to federalize the European Union...and why bother", Journal of European Public Policy, 12(3): 401-418.

van der Eijk, Cees and Franklin, Mark. 2004. "Potential for Contestation on European matters at National Elections in Europe", in Marks, Garry and Steenbergen, Marco (ed.), European Integration and Political Conflict (32-50), New York: Cambridge University Press. 
von Beyme, Klaus. 1987. America As a Model: The Impact of American Democracy in the World, London: Palgrave Macmillan.

Wallace, Helen. 2007, "Adapting to Enlargement of the European Union: Institutional Practice since May 2004", TEPSA Working Paper, Brussels: Trans European Policy Studies Association.

Weiler, Joseph. 1999. The Constitution for Europe. Cambridge: Cambridge University Press

Weingast, Barry. 1995. "The economic role of political institutions: Market-preserving federalism and economic growth", Journal of Law, Economics, and Organization 11 (1): 1-31.

Fernando Mendez obtained his $\mathrm{PhD}$ in political science from the European University Institute in Florence, Italy. He teaches at the University of Zurich and the Swiss Federal Institute of Technology (ETH). He is also a Senior Researcher at the Centre for Research on Direct Democracy, and Director of the e-Democracy Centre, both at the University of Zurich.

[E-mail: fernando.mendez@zda.uzh.ch]

Mario Mendez holds law degrees from the Universities of London, Oxford and the European University Institute. He is a Lecturer in Public Law at the School of Law, Queen Mary University of London. [E-mail: mario.mendez@qmul.ac.uk]

Vasiliki Triga received her PhD in Social and Political Science at the European University Institute in Florence, Italy. She is currently a Senior Researcher at the Centre for Research on Direct Democracy, Zentrum für Demokratie Aarau (ZDA) at the University of Zurich.

[E-mail: vasiliki.trigka@zda.uzh.ch] 
